\title{
IN SEARCHING FOR BUSINESS MODEL OPEN FOR INNOVATIONS ON AGRICULTURAL MARKET - CONCEPTUAL APPROACH
}

\author{
Zenon Pokojski, $\mathrm{PhD}^{1}$
}

Faculty of Economics, Maria Curie-Skłodowska University

\begin{abstract}
Open innovation requires skills to manage various processes of knowledge development, such as the ability to acquire knowledge, its commercialization, development and protection of intellectual property, shaping the relationship between the company and its surroundings. Many companies declare openness to innovations, at the same time the organizational structure, existing procedures, management culture, incentive systems are not ready to seek and transfer knowledge. The biggest challenge for managers is to carry out a transformation process from closed organization to an origination that is open to innovation. The article analyses the possibility of building an organizational and legal structure with the so-called 'permeable borders', open to innovation. After reviewing the literature, analysing the cases of chemical companies, conducting interviews with members of the Grupa Azoty Puławy consortium, I propose a cooperation platform for various organizations operating for the agricultural market which is open to acquiring and implementing innovations, but also for outsourcing.
\end{abstract}

Keywords: open innovations, business model, cooperation platform, foundation JEL codes: O320, O310

\section{INTRODUCTION}

In the Polish agriculture and food industry, the advantage of low value-added products is visible (McKinsey and Company, 2015) $)^{2}$. In order to change this situation and reduce the distance of productivity, one should enter a higher degree of product processing, and thus enter a higher position in the value chain. Agricultural business must become more receptive to innovation. The issue concerns not only increasing expenditures on research and development, but also changing the attitudes and habits of knowledge pro- viders interested in its commercialization as well as its potential recipients. Openness to various external partners is a great opportunity for both science and business in increasing the efficiency and productivity of their resources. The formula of the business model open to innovation indicates possible directions of building competitive advantages on the market.

The knowledge needed in the company is widely dispersed, so it must learn to acquire innovations from various internal and external sources and incorporate them into its business model (Chesbrough and Vanhaverbeke, 2014). However, this model must be

${ }^{1}$ Corresponding author: pl. Marii Curie-Skłodowskiej 5, 20-031 Lublin, Poland, zenon.pokojski@poczta.umcs.lublin.pl, +488153751 73

${ }^{2}$ Poland has a share of $43 \%$ of the total gross value added generated in German agriculture, but only $28 \%$ in processed products. 
ready to seek these innovations from various sources, it must be able to implement them into its business model and convert them to market value. Observation of the Polish market indicates that companies wishing to engage in systemic acquisition of knowledge from the outside are not prepared for that. Organizational structure, existing procedures, management culture, incentive systems are not ready to seek and transfer innovations to organizations. Similarly, reverse transfer, outside, is not popular.

The publication is the result of a research process based on a literature review of management dealing with the issues of open innovation, interviews with members of a consortium established by Grupa Azoty Puławy, research by PWC Polska and participating observation of the author ${ }^{3}$. Its goal is to propose a model of a cooperation platform for various organizations functioning for the benefit of the agricultural market open to acquiring and implementing innovations, but also for their transfer to the external environment.

\section{THEORETICAL BACKGROUND}

Chesbrough (2003) formulated the paradigm of open innovations, assuming that companies can and should use external and internal ideas, as well as external and internal market paths in search of opportunities for their development. Businesses should be more open to sharing innovation, licensing and selling them, if they do not fit their business model (Chesbrough, 2006). He further develops the definition, indicating that open innovation is a dispersed process that is based on a deliberately managed flow of knowledge across organizational boundaries, using financial and non-financial mechanisms in line with the organization's business model to guide and motivate to share knowledge (Bogers and Chesbrough, 2014). Intellectual property should not be a barrier to opening up to innovation. It should be treated as a kind of asset that has its market value, is tradable and should be a source of additional income for the company (Chesbrough, 2017).
In 2012-2013, The Garwood Center for Corporate Innovation at the University of California, Berkeley (USA) US and the Fraunhofer Society in Germany conducted the first extensive open innovation survey on a sample of 2,840 companies in Europe and the United States. The result of this work was a report describing business's attitude to open innovations. We learned, among other things, that $78 \%$ of the surveyed companies confirm the use of open innovation practices, although they are not formalized in a form of applied procedures. However, they explain that formal documentation helps, but the growth of the organizational culture that supports open innovation is at least as important to the effectiveness of innovation processes. None of the companies in the last three years has abandoned this practice, and $71 \%$ say that support for them among the top management of the company is growing. Research also shows that the biggest challenge for managers is to conduct a change process from a closed organization to the organization that is open to innovation (Brunswicker and Chesbrough, 2013).

Opening an enterprise to innovations is likely to affect the company's business model. Interference of external sources of knowledge can change, for example, relations between organizational units of the company, it may also require changes in management (Saebi and Foss, 2015). The authors admit, however, that we still do not know how these processes take place in companies. We do not know much about what is going on inside the company, which helps, and which is detrimental to the implementation of innovative processes ( Du, Leten and Vanhaverbeke, 2014).

\section{MATERIALS AND METHODS}

Grupa Azoty Puławy (GAP), seeking a new formula for acquiring ideas for the development of its research and development projects, referring to the typology of Saebi and Foss (2015), adopted the strategy of building an innovative community. It was decided to build

\footnotetext{
${ }^{3}$ The author describes the case of the Consortium of the Puławy Competence Center from the perspective of a participating observer as the vice-president of Grupa Azoty Puławy, supervising the implementation of the project as in the period 2009-2016.
} 
a cooperation platform between the participants of the project, in order to acquire and develop innovations to improve the efficiency of farming in agriculture, mainly by increasing the efficiency of fertilization. In 2011, a consortium called Puławy Competence Centre (CK) was established. After several years of activity, it was recognized that the adopted formula had exhausted its possibilities of further development. The search for a new model of action, which would be more open to acquiring innovations from the outside, was able to commercialize them at various stages of market maturity, and at the same time was subjected to the pressure of operational efficiency.

The analysis of the experience of such structures as: BASF, MONSANTO, SOLVAY and YARA and an overview of the functioning of ecosystems on the agricultural market, such as: The Fertilizers Institute in the United States, UNIFA - Association of French fertilizer producers, CropLife, Axelera (SOLVAY) from the South-East of France. Also, in 2015, interviews were conducted with consortium members and members of the consortium's Scientific Council, which enabled to define the expectations of the partners and served to prepare a new model concept.

The conducted research proved that the Group was not too open to external initiatives, it also reluctantly provided information about its projects, so the company's boundaries did not become more 'permeable' (Pokojski, 2017). The majority of agricultural market participants in Poland (research institutes, universities, producers of agricultural production resources, suppliers, agricultural entrepreneurs) work in a similar way trying to act on their own, independently of each other, thus the flow of information and knowledge is limited.

\section{CONCEPT OF BUSINESS MODEL OPEN TO INNOVATION}

Brunswicker and Chesbrough (2013) point out that change management from innovations closed within the company's walls to open innovation must entail a number of organizational changes at various levels of the company. Making these changes is extremely difficult. Companies from traditional industries are usually very closed to external innovations. On the other hand, they are looking for new cooperation platforms that would 'force' mechanisms of efficiency and effectiveness in implementing innovative solutions in close cooperation with their partners.

Conducted interviews, analyses, observations and literature review were used to prepare the concept of a platform for cooperation between entities working for various sectors of the agricultural market open to innovation in Poland, which is the most optimal from the organizational and legal point of view and the ability to source funding for knowledge exchange. It was assumed that the supply and demand side of innovation (Orłowski, 2013) should jointly initiate and implement research and development projects reducing the risks and costs of knowledge transfer.

Several assumptions were made to build the concept of the model:

- The new model of cooperation platform for organizations interested in the agricultural market should be more open to external innovations.

- Relationships between partners in the target organizational and legal structure should be based on economically justified projects.

- Decision-making processes within the structures of interested innovation partners should take into account the newly created entity.

- The model should create greater opportunities to raise funds from external sources and encourage partners to engage their resources to carry out joint innovation projects.

- An important function of the model should be the image aspect that serves to increase the credibility of the communication message by an 'independent' expert addressed to various agricultural environments.

- The model is to ensure the construction of a new formula for the transfer of knowledge to business, freeing and creating the potential of R\&D innovation, but it is not intended to duplicate the functions and processes of research and development taking place at partners' organisations.

In constructing the open innovation platform model, it was assumed that the basis for its construction will be the establishment of a new entity created by all interested members of the consortium. The analysis of various organizational and legal forms allowed 
us to point to the foundation as the form that best meets the expectations of the consortium members. Appropriate regulations in the statute should secure the interests of all project participants.

The asset of the foundation is also the image aspect. It allows to build an effective reputation in the eyes of its main stakeholders. Expert competences can be used in the Think-tank formula. Many nongovernmental organizations in Poland, having such a character, operate in the form of foundations. In the eyes of the public, a foundation is better perceived as an independent expert. Advocacy of such an organization will certainly increase the value of assets of non-material partners.

In the proposed model, the participating entities may, on the one hand, improve their economic results by reducing innovation costs, and on the other, generate additional revenues through technology sales, licensing agreements, spin-offs, when innovation cannot be commercialized with profit on the agricultural market. In this concept, it is emphasised that ideas are generated not only by the entities interested in the project, but are also obtained from external sources (Chesbrough and Vanhaverbeke, 2014).
Figure 1 presents a model of cooperation platform for various entities open to innovations working for the benefit of the agricultural market. The innovation supply and demand side participate in innovation processes for the same market segment.

The Foundation may also establish and participate in commercial companies, if it is justified by the implementation of statutory objectives. It may therefore, in business-specific cases, establish special purpose vehicles (SPVs) to manage the risk of running certain projects.

According to the basic assumptions of the open innovation model, the foundation would be the subject of:

- Initiating and supporting the implementation of research and development and innovation activities using the available resources of project participants for this purpose.

- Enabling optimal use of the know-how and resources of partners for the needs of other entities, seeking ways to use them differently.

- Enabling two-way diffusion of knowledge from the scientific environment, the market to business partners and in the opposite direction.

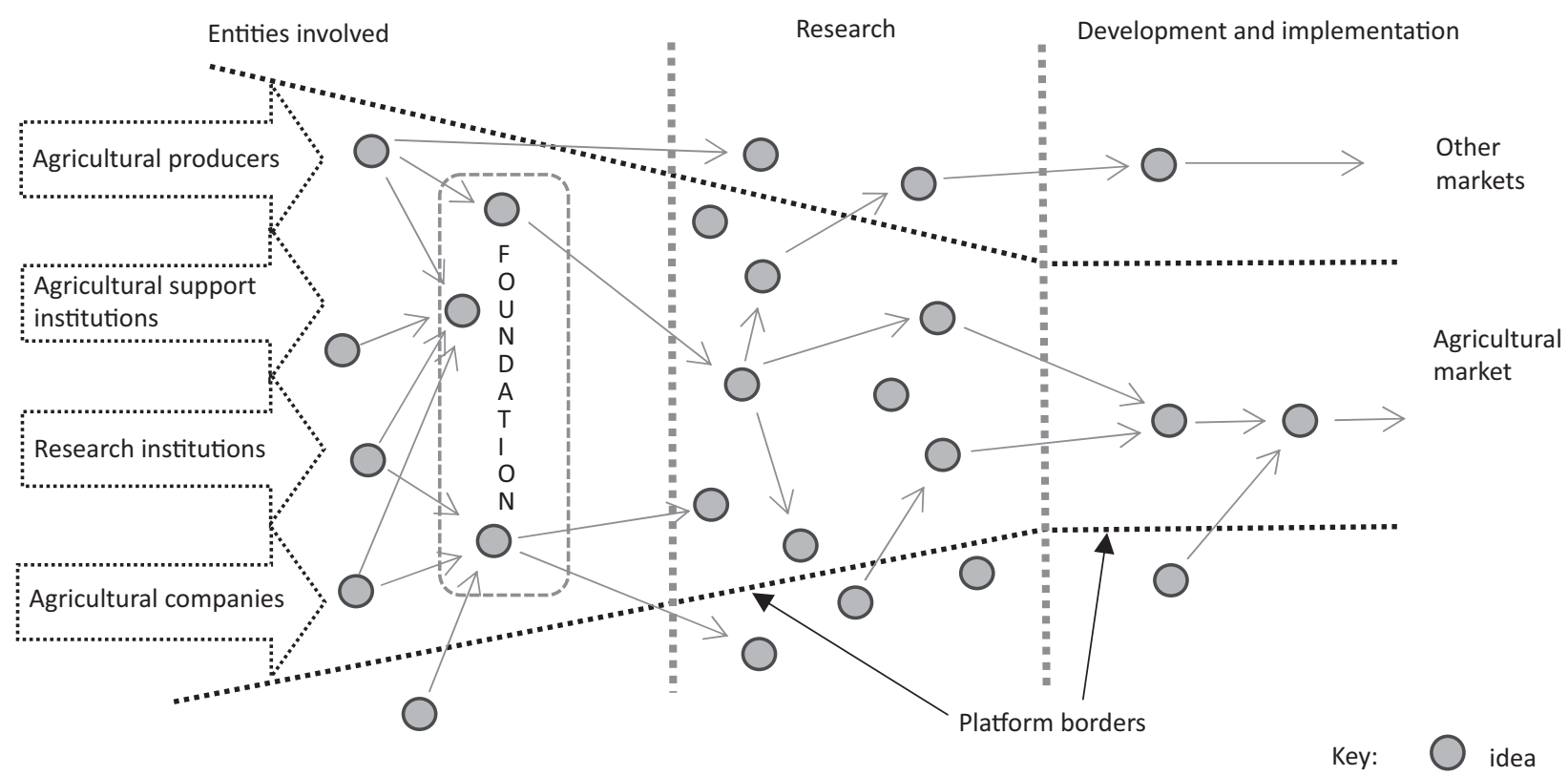

Figure 1. Model of cooperation platform for entities from different sectors in the framework of open innovation scheme

Source: Own elaboration based on Chesbrough (2003). 
- Influencing the change of the organizational culture towards opening to cooperation and seeking new areas of synergy resulting from it.

- Shaping the image and influencing the behaviour of the participants of the agricultural market.

Foundation should show initiative and undertake research and development projects in which partners could participate if they consider it economically or commercially justified. Such a formula of cooperation creates much greater opportunities to obtain additional sources of financing for high-class projects, including the possibility of using financing from external sources, primarily the EU.

The proposed concept assumes some changes in the management of entities participating in it, for example regarding the permeability of the organization's boundaries for innovative processes or the ability to acquire additional resources.

\section{CONCLUSIONS}

Many companies declare their openness to innovations, stating at the same time that there are no formal procedures for their application. The process of making these changes in the company is a very difficult process. Companies looking for openness to innovation adopt different strategies of searching for and acquiring innovations. One solution may be to build a model of cooperation platform for various organizations that combines interest in a similar market segment.

The author recommends the creation of a mixed legal and organizational structure that would be based on a form of foundation. In order to manage the risk of running certain projects, the foundation would set up special purpose vehicles (SPVs).

The proposed solution will improve absorption and openness to external ideas, ensure effective management of projects, improve the ability to acquire additional resources, including EU funds, enforce the effectiveness and efficiency of implemented activities - as it is result oriented. Regardless of the indicated benefits, the entities participating in the platform gain a partner with expert knowledge who supports the construction of their market value.
However, it should be borne in mind that without the support of the top management of the cooperating entities, openness to innovation will not make any organization more effective in this area.

\section{REFERENCES}

1. Bogers, M. Chesbrough, H. (2014). Explicating open innovation: Clarifying an emerging paradigm for understanding innovation. In: Chesbrough, H., Vanhaverbeke, W., West, J. (eds.), New frontiers in Open Innovation. Oxford University Press, Oxford.

2. Brunswicker, S., Chesbrough, H. (2013). Managing open innovation in large firms. Survey report Executive Survey on Open Innovation. Fraunhofer, Stuttgart.

3. Chesbrough, H. (2003). Open innovation: The New Imperative for Creating and Profiting from Technology. Harvard Business School Publishing Corporation, Boston.

4. Chesbrough, H. (2006). Open business models: How to thrive in the new innovation landscape. Harvard Business Press, Boston.

5. Chesbrough, H. (2017). The Future of Open Innovation: The future of open innovation is more extensive, more collaborative, and more engaged with a wider variety of participants. Research-Technology Management, 60 (1), pp. 35-38. https://doi.org/10.1080/08956308.2017. 1255054

6. Chesbrough, H., Vanhaverbeke, W. (2014). A classification of open innovation and open business models. In: Chesbrough, H., Vanhaverbeke, W., West, J. (eds.), New frontiers in Open Innovation. Oxford University Press, Oxford.

7. Du, J., Leten, B., Vanhaverbeke, W. (2014). Managing open innovation projects with science-based and market-based partners, Research Policy, 43 (5), pp. 828-840. DOI: $10.1016 /$ j.respol.2013.12.008

8. Grupa Azoty Puławy (2015). Materiały wewnętrzne wspólnego zespołu pracowników pionu Technologii i Rozwoju Grupy Azoty Puławy oraz firmy doradczej PWC [Internal materials of a joint team of employees of the Technology and Development Division of Grupa Azoty Puławy and the consulting company PWC]. Puławy.

9. McKinsey and Company (2015). Polska 2025 - Nowy motor wzrostu w Europie [Poland 2025: Europe's new growth engine]. Raport. Warszawa.

10. Orłowski, W. (2013). Komercjalizacja badań naukowych w Polsce. Bariery i możliwości ich przełamania 
[Commercialization of scientific research in Poland. Barriers and possibilities of breaking them]. PWC Polska, Warszawa.

11. Piller, F., West, J. (2014). Firms, Users, and Innovation. In: Chesbrough, H., Vanhaverbeke, W., West, J. (eds.), New Frontiers in Open Innovation. Oxford University Press, Oxford.

12. Pokojski Z. (2017). W poszukiwaniu modelu organizacji zarządzającej innowacjami w formule ,open in- novation" - studium przypadku [Looking for a model of innovation management organization in the 'open innovation' formula - case study]. Zeszyty Naukowe Wyższej Szkoły Biznesu, 49, pp. 45-62.

13. Saebi, T., Foss, N.J. (2015). Business Models for Open Innovation: Matching Heterogenous Open Innovation Strategies with Business Model Dimensions. European Management Journal, 33 (3), pp. 201-213. DOI: 10.1016/j.emj.2014.11.002 